\title{
Ghrelin and its role in gastrointestinal tract tumors (Review)
}

\author{
IRENE ALEXANDRA SPIRIDON ${ }^{1}$, DELIA GABRIELA APOSTOL CIOBANU ${ }^{1}$, \\ SIMONA ELIZA GIUȘCA $\breve{~}^{1}$ and IRINA DRAGA CĂRUNTU ${ }^{2}$
}

Departments of ${ }^{1}$ Pathology and ${ }^{2}$ Histology, 'Grigore T. Popa' University of Medicine and Pharmacy, Iași 700115, Romania

Received April 11, 2021; Accepted June 23, 2021

DOI: $10.3892 / \mathrm{mmr} .2021 .12302$

\begin{abstract}
Ghrelin, an orexigenic hormone, is a peptide that binds to the growth hormone secretagogue receptor; it is secreted mainly by enteroendocrine cells in the oxyntic glands of the stomach. Ghrelin serves a role in both local and systemic physiological processes, and is implicated in various pathologies, including neoplasia, with tissue expression in several types of malignancies in both in vitro and in vivo studies. However, the precise implications of the ghrelin axis in metastasis, invasion and cancer progression regulation has yet to be established. In the case of gastrointestinal (GI) tract malignancies, ghrelin has shown potential to become a prognostic factor or even a therapeutic target, although data in the literature are inconsistent and unsystematic, with reports untailored to a specific histological subtype of cancer or a particular localization. The evaluation of immunohistochemical expression shows a limited outlook owing to the low number of cases analyzed, and in vivo analyses have conflicting data regarding differences in ghrelin serum levels in patients with cancer. The aim of this review was to examine the relationship between ghrelin and GI tract malignancies to demonstrate the inconsistencies in current results and to highlight its clinical significance in the outcome of these patients.
\end{abstract}

\section{Contents}

1. Introduction

2. Ghrelin and its receptors

3. Experimental studies and their role in understanding the ghrelin axis in cancer development

4. Ghrelin and GI tract tumors

5. Ghrelin interactions and expression in neoplasia outside the GI tract

6. Conclusions

Correspondence to: Dr Irene Alexandra Spiridon, Department of Pathology, 'Grigore T. Popa' University of Medicine and Pharmacy, 16 University Street, Iași 700115, Romania

E-mail: spiridon.irene@umfiasi.ro

Key words: ghrelin, growth hormone secretagogue receptor, carcinogenesis, cancer, pathology, prognosis

\section{Introduction}

Ghrelin was first discovered in 1999 and was described as an endogenous ligand of the growth hormone secretagogue receptor (GHSR) (1). Ghrelin is produced in the fundic area of the stomach, where it is secreted directly into the bloodstream (2). Initially thought to regulate growth hormone (GH) secretion, ghrelin has been shown to serve various biological functions. A main role of ghrelin is in the gut-brain interaction (3), with expression in the hypothalamus and pituitary (4). This hormone is also known to serve a key role in appetite stimulation (5), gastric motility and acid secretion (6), stress and anxiety (7), and regulation of the circadian rhythm (8). Ghrelin is typically released when the stomach is empty, suggestive of its involvement in endocrine regulation of motility-dependent interdigestive gastric secretion (9).

Ghrelin has long been considered to be involved in tumorigenic proliferation and although its precise role is still uncertain, it has received increasing attention in research regarding gastrointestinal (GI) neoplasia. The immunohistochemical (IHC) expression of ghrelin has been documented in a number of endocrine and non-endocrine tumors $(10,11)$, but it is still unclear whether an autocrine/paracrine loop or another type of interaction is involved. At present, it has not yet been reported if the expression of ghrelin and its receptors in tumor cells are protective against neoplasia or whether they stimulate carcinogenesis. Therefore, this review provides an assessment of the current literature, presenting the emerging trends and highlighting potential gaps in current knowledge regarding the implications of ghrelin from its production to the interaction with its known receptors (known as the ghrelin axis) in digestive malignancies.

\section{Ghrelin and its receptors}

Ghrelin is primarily produced in the stomach (12), where $\mathrm{X} / \mathrm{A}$-like cells are found in abundance in oxyntic glands, close to parietal cells; in addition, ghrelin displays rare colocalization with other hormones (13). Ghrelin cells are closed-type cells, having no contact with the lumen (2) and release their secretions within the vascular bed $(14,15)$. However, ghrelin and its gene transcripts have also been identified in other enteroendocrine cells, namely enterochromaffin cells, S cells, I cells, L cells and M cells (16-20). Ghrelin is also produced in variable amounts in other segments of the GI tract (duodenum, jejunum, ileum, colon) (21-24), as well as in 
the lungs, kidneys, testes, prostate, ovaries, breasts, pituitary and hypothalamus (25-28). Ghrelin release is activated by a series of receptors, like $\beta 1$-adrenergic, calcitonin gene-related peptide, glucose-dependent insulinotropic polypeptide and secretin receptors. Moreover, ghrelin is inhibited by both short-chain and long-chain fatty acids, lactate, extracellular calcium, amino acids and somatostatin receptors (9).

Genetic mapping has placed the ghrelin gene on the short arm of chromosome 3 (3p25-26) (27), with an initial gene product known as pre-proghrelin $(29,30)$. Pre-proghrelin is a 117 amino acid pre-protein, containing a 23-amino acid $\mathrm{N}$-terminal signal peptide that is cleaved to form the 94 amino acid peptide, proghrelin (31). Proghrelin is then split by a prohormone convertase to produce the 28 amino acid ghrelin peptide and a 66 amino acid C-terminal fragment (known as C-ghrelin), which gives rise to the hormone obestatin (32).

Acylated ghrelin, desacyl ghrelin and C-ghrelin, have been found in ghrelin-secreting cells and in the circulation, and have been previously described as peripheral forms of ghrelin (33-36). Desacyl ghrelin shows a remarkable predominance in peripheral blood $(35,37)$, mainly owing to it being the most secreted and more stable form of ghrelin $(34,38)$. Alternative ghrelin-related peptides and mRNA splice variants were subsequently identified $(31,39)$. With multiple variants described to date, the intron 1 (In1)-ghrelin variant has an alternative C-terminal tail but displays high areas of conservation to ghrelin that are essential in the process of acylation and allow receptor binding (40). Ghrelin must be acylated with an octanoyl group to activate its receptor, which is achieved by a post-translational enzymatic change initiated by ghrelin-o-acyltransferase (GOAT) (41). Although this process is necessary for ghrelin to be highly physiologically active through its receptor $(42,43)$, certain studies also suggest a metabolic role for desacyl ghrelin $(44,45)$.

The ghrelin receptor, GHSR, belongs to the G-protein coupled receptor family (46). There are two isoforms of the GHSR, GHSR1a and GHSR1b, both of which are widely expressed throughout the body. First identified in the pituitary and hypothalamus, GHSR1a is expressed in a broad range of tissues (bone; adipose tissue; lymphoid tissue) and organs, including the stomach, intestine, pancreas, spleen, thyroid gland, prostate, ovaries, testes, adrenal glands, kidneys, heart and lungs (47-50). GHSR1a is considered to be a functional receptor, as it mediates several of the effects of ghrelin, whereas GHSR 1b is to be a considered a non-functional receptor, devoid of signal transduction activity (51). The expression of GHSR1b is mostly similar to that of its splicing variant with regard to localization, albeit it is different in intensity, with higher detectable levels of mRNA $(11,25,50)$.

Acylated ghrelin preferentially binds to GHSR1a, leading to GH secretion. Both the acylated and desacylated forms have been identified as functionally active in local and systemic processes, such as adipogenesis and lipid retention (52-55). However, desacyl ghrelin does not bind to GHSR 1a, suggesting its effects are GHSR-independent, with its cognate receptor remaining unknown $(56,57)$. Desacyl ghrelin mainly exerts nonendocrine activities, with involvement in vascular remodeling, cardiovascular stability, muscle atrophy, cachexia and lipolysis (38,58-62). A schematic illustration of the main steps in the ghrelin circuit, from production to interaction with its receptor, is presented in Fig. 1.

Ghrelin is a hormone involved in a number of physiological processes outside of the GI tract; it is a key participant in the interaction between the enteric and the central nervous systems, with implications in physical, mental and behavioral changes owing to the regulation of the circadian rhythm, and stress and anxiety levels $(3,7,60)$. In the GI tract, ghrelin interacts with all organs, stimulating gastric acid secretion, increasing GI motility (6) and modulating glucose levels through an increase of pancreatic insulin release and through insulin sensitivity (63). In the liver, ghrelin promotes gluconeogenesis and lipogenesis $(64,65)$, the latter also being its main action in adipose tissue (66).

Even though the physiological roles of ghrelin are yet to be fully revealed, it has been demonstrated that ghrelin contributes to the pathology of a multitude of diseases. Its orexigenic role is well established $(5,67,68)$; however, ghrelin also serves a function in inflammatory processes (69). The presence of ghrelin and its receptors on human leucocytes ( $\mathrm{T}$ lymphocytes and macrophages) was noted as early as 2004 (70), with proven anti-inflammatory effects in both animal and human studies, in acute (71-74) and chronic settings (75-78), as well as in a neoplastic context (79). Ghrelin receptors have also been identified in cardiac tissue (80), where they modulate cardiac function and healing by influencing myocardial contraction (81), perfusion (82) and post-myocardial infarction-changes $(41,72,83)$. In the lungs, ghrelin can attenuate pulmonary blood pressure through vascular remodeling and mitigate the changes induced by acute lung injury $(84,85)$. Ghrelin also serves a role in the intricate pathologies of anorexia and cachexia $(86,87)$ as well as neurodegenerative disorders, such as dementia (88), multiple sclerosis (89) and amyotrophic lateral sclerosis (90). The pleiotropic effects of the ghrelin axis are summarized in Fig. 2.

Present in both endocrine and non-endocrine tumors, such as breast, prostate, testicular, GI, pancreatic, renal, thyroid, lung and adrenal tumors $(11,91-94)$, ghrelin and its receptors may give rise to a complex set of interactions that contribute to neoplastic development at various stages. Although the precise role of ghrelin is still uncertain, numerous studies have used different experimental approaches to document the involvement of the ghrelin axis in neoplasia.

\section{Experimental studies and their role in understanding the ghrelin axis in cancer development}

Experimental studies have investigated the connection between ghrelin and neoplasia, in attempts to uncover a novel prognostic factor or to find missing links in the processes of tumorigenesis, invasion and metastasis. The majority of in vitro studies have focused on ghrelin and GHSR splice variants expression in various tumor cell lines, investigating the effects of ghrelin on tumor development. A summary of these findings regarding GI tumor cells and highlighting the diversity of results published on this topic can be found in Table I. Ghrelin has also been reported to be expressed in experimental studies using cell lines of leukemia (95), breast carcinoma (96), pulmonary adenocarcinoma (97), pancreatic ductal adenocarcinoma (98), prostate carcinoma (99), 


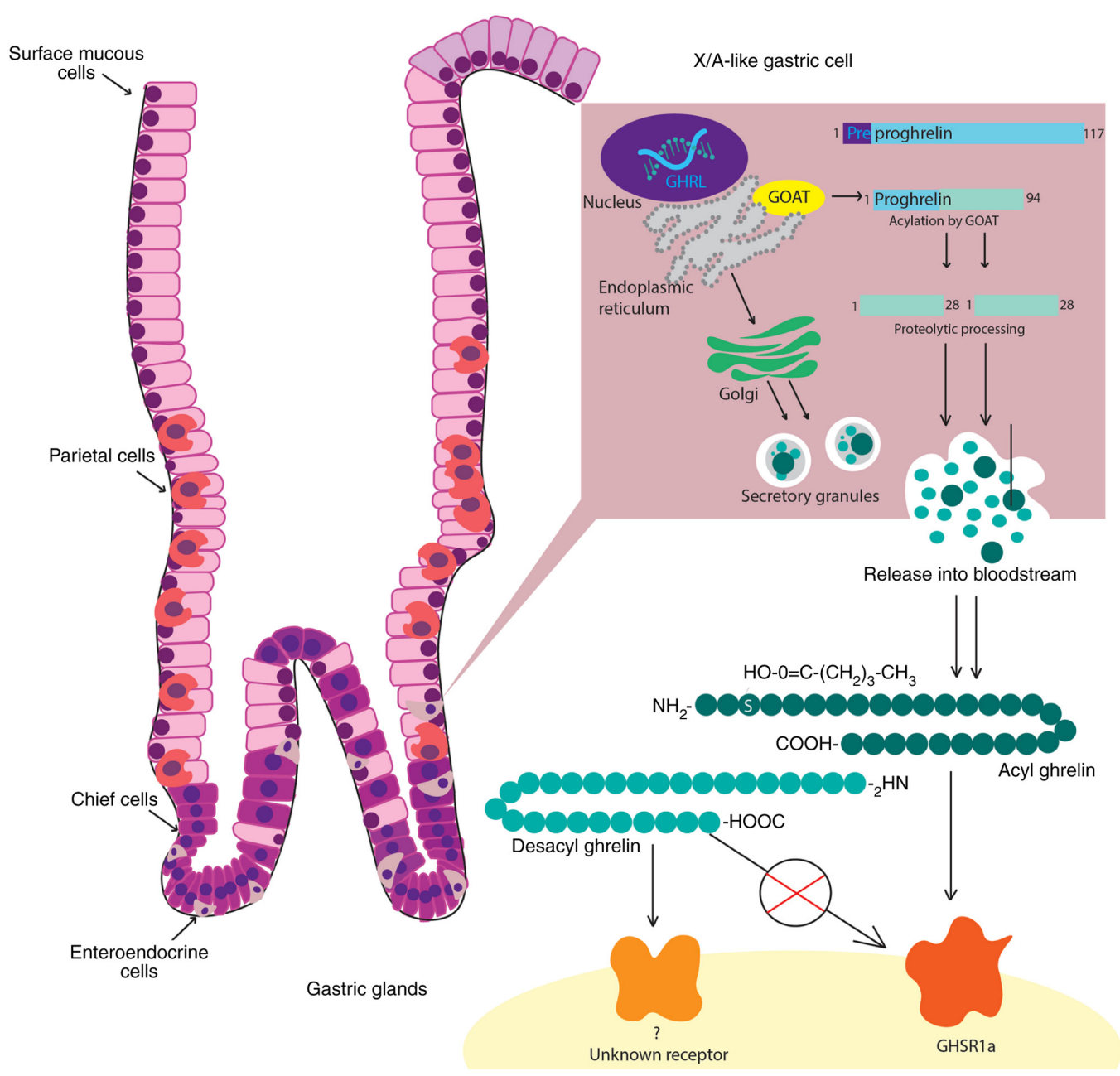

Figure 1. Synthesis of ghrelin and its mechanisms of action. Ghrelin is produced by X/A-like enteroendocrine cells located in the stomach. GOAT is an enzyme responsible for the acylation of this hormone, located within the endoplasmic reticulum. Proghrelin is cleaved in the Golgi body to form ghrelin, in its acylated and desacylated forms, which are secreted directly into the bloodstream. Circulating ghrelin can also be converted to the desacylated form, which is predominant in the peripheral blood. The known receptor for ghrelin is GHSR 1a, which does not bind desacyl ghrelin, the receptor for desacyl ghrelin remains unknown. GHRL, growth hormone secretagogue receptor ligand; GHSR, growth hormone secretagogue receptor; GOAT, ghrelin-o-acyltransferase.

gastric adenocarcinoma (100) and colorectal adenocarcinoma (101,102). and it has shown pleiotropic effects in the vast majority of these tumor cell lines (11).

Ghrelin expression is less variable compared with the expression of its receptors, which is highly variable between different types of cancer. GHSR1a and GHSR $1 b$ are most often co-expressed, with GHSR1a expression levels demonstrated to be higher compared with those for GHSR $1 b$ in oral squamous cell carcinoma (SCC) and gastric cancer (GC) cell lines $(100,103)$. For breast cancer cell lines, an initial study reported that lines MDA-MB-231, MCF-7, MDA-MB-435 and T47D have positive IHC expression of the ghrelin/GHSR axis (27), whereas GHSR1a mRNA could not be detected in lines MDA-MB231, MCF7 and T47D, in spite of specific binding of ghrelin in these cells, implying that an unidentified interaction or binding site modulates these effects (96). High GHSR 1b expression was identified in breast cancer cell line MDA-MB-231 (39). A similar difference in expression was demonstrated in colon cancer cell lines (101).

The effects of ghrelin can vary according to the type of cancer. Previous studies have found ghrelin can have a proliferative effect on a number of cancer cell lines including breast (27), prostate (28), gastric (100), colorectal $(101,102,104)$, oral $(103)$, pancreatic (98), adrenocortical (105) and endometrial (106). Conversely, D-Lys-growth hormone releasing peptide 6 or other ghrelin-specific antibodies can antagonize ghrelin and inhibit this proliferative effect (101). Certain studies attribute this proliferative effect to the desacyl form $(27,91,95)$, suggesting that in these cell lines ghrelin can stimulate cell proliferation via an autocrine pathway independent of GHSR1a (95). However, ghrelin has also been shown to inhibit proliferation and exhibit an antiapoptotic effect in cell lines of the same cancer type, as is the case for breast carcinoma cell lines MCF7 and MDA-MB231 (96) and prostate carcinoma cell lines PC-3 and DU-145 (91). Both acylated and deacylated ghrelin inhibit DU-145 cell proliferation $(91,99,107)$. A recent study on chemosensitive ovarian cells demonstrated that acylated ghrelin promotes cell proliferation and survival, and inhibit apoptosis through its interaction with GHRS1a via the PI3K/Akt signaling pathway, thereby rendering the cells resistant to chemotherapy, even at very low levels (108). 


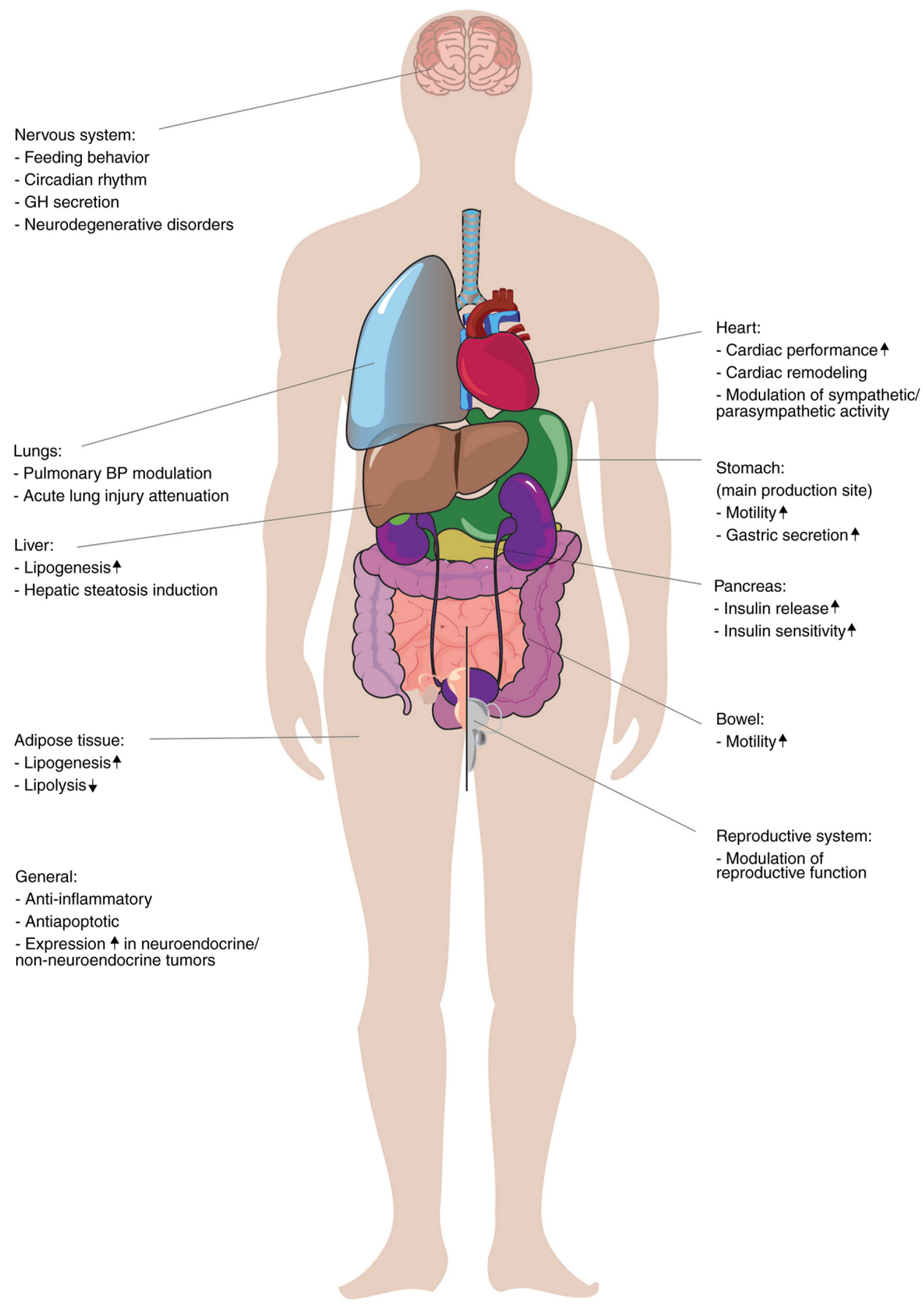

Figure 2. Overview of the implications of the ghrelin axis in pathophysiological processes in the body. The physiological functions of ghrelin extend well beyond the local influence on GI motility, spanning over a multitude of organs and systems. Ghrelin is a key element of the brain-gut axis and plays a major role in manipulating satiety, in the plasticity of adipose tissue and modulation of metabolic pathways in various organs. Furthermore, ghrelin is implicated in complex pathological processes, such as inflammation, cardiac remodeling or tumorigenesis.

The ghrelin splice variant, In1-ghrelin, can increase the proliferation rate of the MDA-MB-231 breast cancer cell line (39) and stimulate proliferation and migration of MCF-7 and MDA-MB-231 cells (109). Expression of this variant was also found in pancreatic adenocarcinoma cell lines, which do not express ghrelin, wherein it enhanced the proliferation and migration of tumor cells (110).

To better document and understand these effects, the activation pathway of ghrelin has been examined extensively, and numerous pathway activation mechanisms have been identified. Through the interaction of ghrelin and GHRS the
$\mathrm{PI} 3-\mathrm{K} / \mathrm{Akt} / \mathrm{mTOR}$ signaling pathway is able to mediate the migration and invasiveness of pancreatic adenocarcinoma cells (98). One study demonstrated that NF- $\mathrm{\kappa B}$ signaling pathway activation can contribute to ghrelin-induced cell migration in glioma cells (111). Furthermore, Lin et al (94) determined ghrelin has diverse implications in tumorigenesis and tumor spread, with the ability to promote metastasis in the case of renal cell carcinoma (RCC) via Snail, a transcriptional repressor of E-cadherin, and invasion through the upregulation of the kinase Aurora A, an activating mechanism which was also associated with a poor prognosis (112). Similarly, 


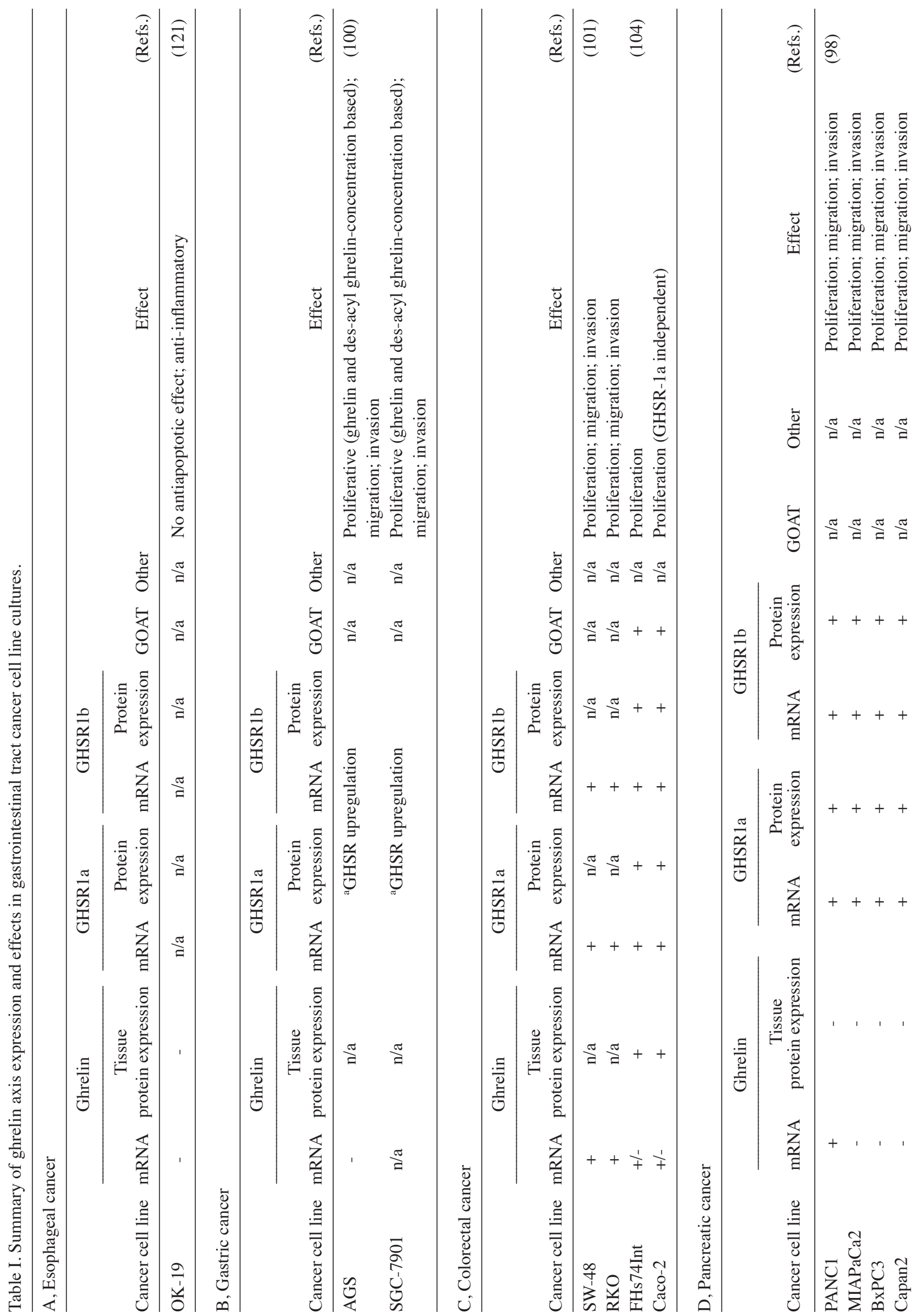


invasion in GC was determined to be a result of GHSR/NF- $\mathrm{kB}$ signaling pathway activation (100).

\section{Ghrelin and GI tract tumors}

Although ghrelin serves a known role in the inflammatory processes of the GI $(113,114)$, data regarding its promoting role in GI carcinogenesis is still controversial. Studies on malignant cell lines have shown conflicting results, as aforementioned. Therefore, research has now shifted from cell line experiments to analyzing tissue expression and circulating levels of ghrelin and its isoforms. The complex dynamics of ghrelin in GI tumors is described in Table II, which provides an integrated overview of the representative results in this research field.

Esophageal cancer. In the esophagus, expression of ghrelin was first demonstrated in SCC by IHC, with tissue ghrelin levels correlating with degree of differentiation, depth of tumor invasion, lymphovascular invasion and tumor stage (115). However, ghrelin expression levels showed no correlation with patient survival (115). IHC detection of ghrelin expression in esophageal adenocarcinoma was undetectable (116). Ghrelin serum levels have an inverse relationship with the risk of developing esophageal malignancies, especially SCC $(93,117)$, and patients with a low ghrelin level are seven-times more likely to develop this histological subtype (117). This unexpected relationship between ghrelin levels and the risk of malignancy has been validated in a larger cohort study (118).

Compared with esophageal SCC, ghrelin serum levels did not correlate with the risk of developing esophageal adenocarcinoma (93). High serum concentrations of ghrelin $(>3,200 \mathrm{pg} / \mathrm{ml})$ were associated with a lower risk of developing esophageal adenocarcinoma in overweight patients with a body mass index (BMI) $>25$ (119). With well-known orexigenic effects, ghrelin may prove to be the basis for the association between abdominal obesity and Barrett's esophagus (BE) (120). A case-control study involving 886 patients with a diagnosis of $\mathrm{BE}$ demonstrated that higher ghrelin serum concentrations were positively associated with an increased risk of $\mathrm{BE}$, irrespective of Helicobacter pylori infection and BMI (120). A positive association between ghrelin and BE development was also supported in another study (121). Upregulated expression of GHSR in BE compared with normal esophageal mucosa has also been reported (122). However, no correlation between ghrelin levels and the risk of $\mathrm{BE}$ was found in a recent meta-analysis compared with other adipokines, but only two studies approaching this interaction were considered (123).

Considering the various factors that influence ghrelin production, recent studies have looked at digestive tract malignancies from a broader perspective. For example, serum levels of ghrelin are correlated with nutritional status (124), with similar levels of active (acylated) and desacyl ghrelin in a balanced (well-nourished vs. malnourished) population of patients with esophageal cancer; it has been argued that active ghrelin is positively correlated with energy metabolism. Together, with a positive correlation with IL-6 levels, these findings may suggest the existence of a form of ghrelin resistance (125). Ghrelin serum levels also correlate with inflammatory responses and high levels have been observed in 


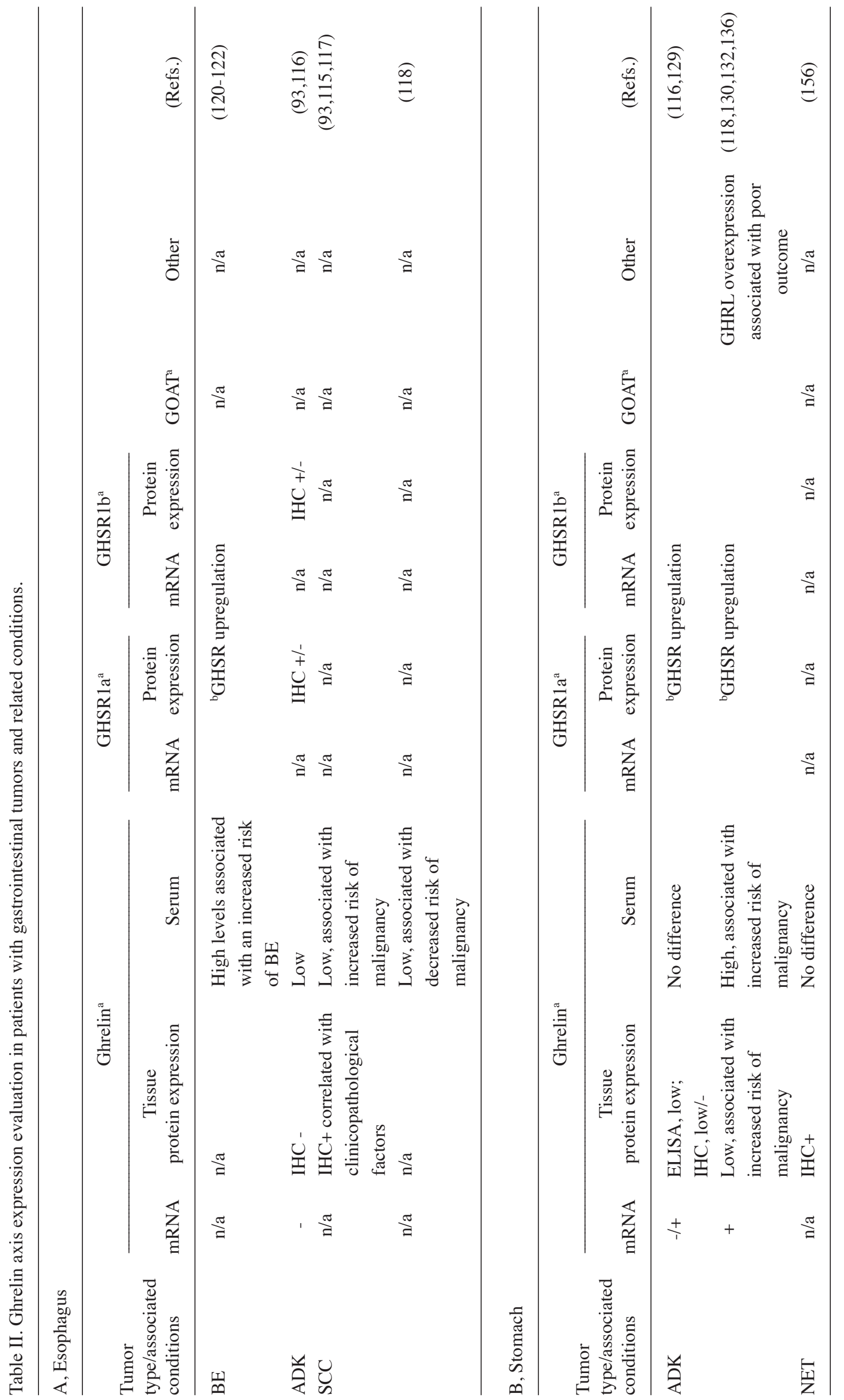




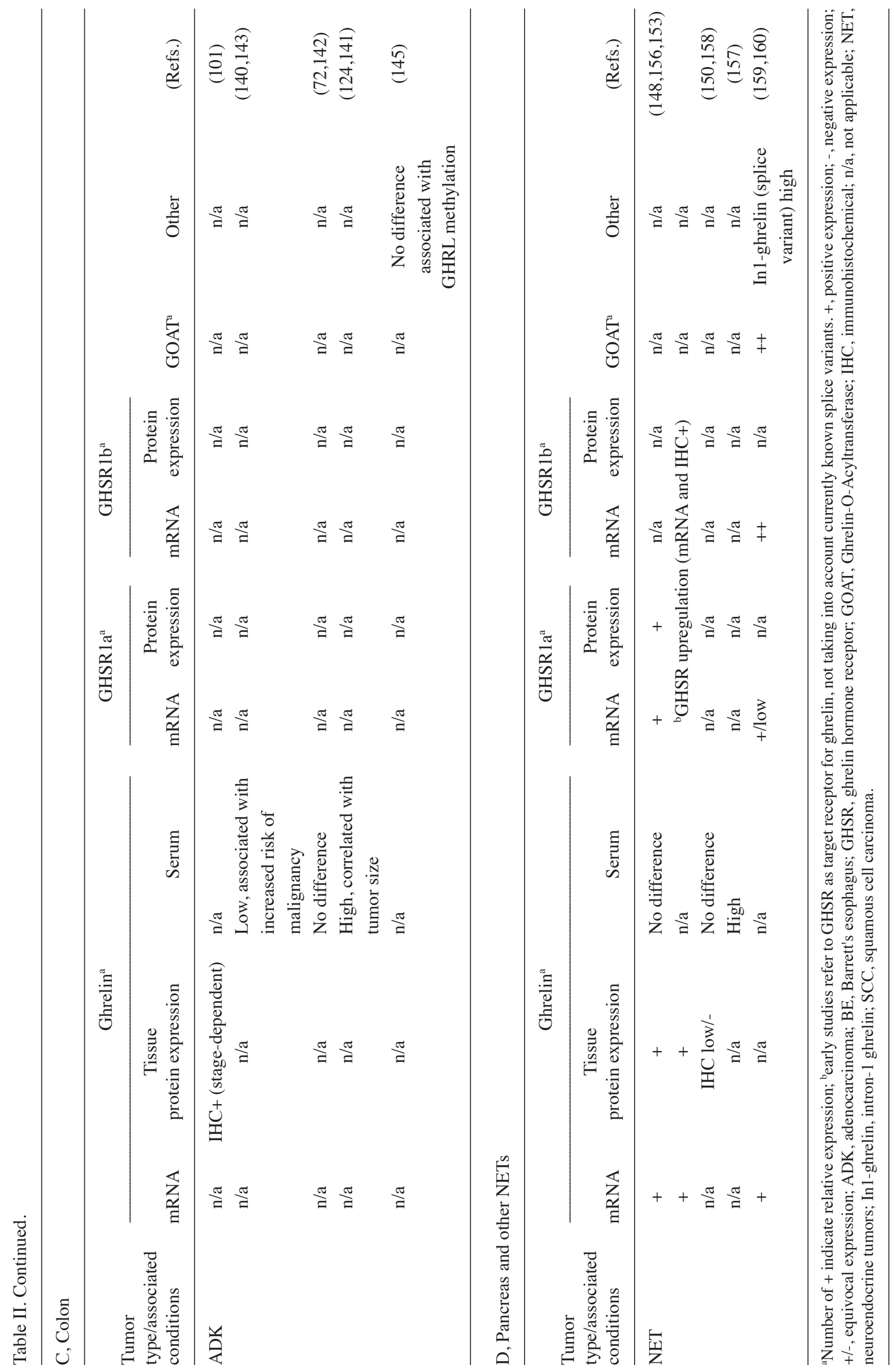


a high-inflammation group of patients with GI neoplasms (124), a finding which could be further explored and integrated into the context of inflammation as a prognostic factor for these malignancies $(126,127)$.

$G C$. Ghrelin axis expression determined by IHC examination shows undetectable levels in gastric adenocarcinoma (116). However, previous studies have a limited number of patients which may make it difficult to draw conclusions. In a study of 10 patients, none tested ghrelin-positive (116), these findings were supported by a similar study analyzing 9 patients with gastric adenocarcinoma (128).

The fluctuation of ghrelin levels over time highlights the potential role of this peptide as a biomarker in gastric malignancies (118). A study on a small cohort of Korean patients with GC showed a 10-fold increase in plasma ghrelin levels of these patients (129). However, ghrelin levels of the tumor tissue were lower compared with those of the normal gastric mucosa, suggesting that gastric tumorigenesis can inhibit ghrelin production in the adjacent mucosa (129). Furthermore, certain studies have demonstrated a significant increase in the risk of non-cardia GC and esophago-gastric junction cancer in individuals with lower baseline serum ghrelin concentrations, changes which occur early in the carcinogenic process $(93,130)$. The risk of these diseases remains increased, irrespective of H. pylori infection (130).

Ghrelin levels can fluctuate depending upon lesions associated with the gastric mucosae with certain studies indicating a reduction in ghrelin plasma levels in cases of $H$. pylori infection, which steadily increase following the eradication of infection $(129,131,132)$. In addition, a histologically higher degree of gastric atrophy seems to correlate with a lower plasma ghrelin concentration (132).

Different surgical approaches seem to radically influence ghrelin levels in patients with GC. Ghrelin levels were higher in patients who had a distal gastrectomy compared with those who had a total gastrectomy, and the physiological regulation of ghrelin secretion and plasma levels was unaffected due to preservation of the gastric fundus (133). In patients with proximal resection, postoperative ghrelin increased more slowly compared with that in patients after fundus-preserving resection (134). Takachi et al (135) demonstrated that there was a significant decrease in the concentration of ghrelin following total gastrectomy, with very low levels observed in the long-term follow-up. Furthermore, Zub-Pokrowiecka et al (133) demonstrated that plasma levels of ghrelin were lower in patients with GC and in those who formerly had GC and undergone surgery 4-5 years previously, compared with the healthy control group.

Ghrelin alone may not be a useful biomarker in evaluating the risk of gastric malignancies, but when coupled with other early detection biomarkers, such as pepsinogen I and pepsinogen I/II ratio, as part of a complex panel it may provide higher accuracy (118). Recent advances in the field point towards the potential role of the ghrelin gene, growth hormone secretagogue receptor ligand (GHRL), as a poor prognosis biomarker in GC (136). A study involving 295 patients with GC and data from 4 gene expression microarrays, found 12 upregulated and 59 downregulated differentially expressed genes, with high expression of GHRL associated with poor overall survival of patients with GC (136).
Colorectal cancer $(C R C)$. The interaction between ghrelin and its receptors, as demonstrated through IHC and molecular studies, is indicative of the presence of an autocrine/paracrine mechanism involved in colorectal carcinogenesis $(101,137)$. In $\mathrm{CRC}$, the ghrelin axis serves a role in the initial stages of carcinogenesis, with positive expression of ghrelin and its receptors in low-grade tumors, as opposed to almost complete loss of expression in high-grade tumors (101). Axis upregulation has also been demonstrated by Liu et al (138) in well-differentiated and moderately differentiated adenocarcinomas, whereby the role of promoting cell growth in CRC was attributed to the interaction of ghrelin with the GHSR1a receptor. However, in spite of this Waseem et al (101) demonstrated that the expression levels of ghrelin and its orphan GHSR1b receptor were increased in patients with CRC, contrary to the decrease of GHSR1a with advancing tumor stage. Although tissue expression of ghrelin seems to have a positive correlation with tumor stage, a study on 110 patients with CRC failed to correlate ghrelin plasma levels with any CRC clinicopathological features (101).

Increased tissue expression of ghrelin and its receptors in $\mathrm{CRC}$ has initiated the idea of its role as a potential biomarker. However, even though this research area has attracted the interest of numerous research groups it is not without controversy. An initial study on a small sample of 20 patients found no difference in circulating ghrelin levels in patients with CRC compared with a control group and no correlation with tumor clinicopathological characteristics (139). A similar study on a group of 29 patients with lower GI tract malignancies, found a statistically significant difference in ghrelin levels between patients with CRC and the control group and noticed a decrease in ghrelin levels with tumor progression (140). This study therefore advanced the idea of ghrelin serum levels as being inversely correlated with tumor aggressiveness and their potential use as a prognostic parameter (140).

The role of circulating ghrelin in the evaluation of patients with CRC was demonstrated by Nikolopoulos et al (141), indicating a significant positive correlation between ghrelin levels and tumor size. Ghrelin plasma levels were increased in end-stage disease and were correlated with the degree of differentiation, being higher in poorly differentiated CRC. However, no significance was detected in using ghrelin as a predictor of CRC survival (141). A similar study found no difference in ghrelin peripheral blood expression between patients with CRC compared with the control group (142). Perioperative serum levels were reported by Zhu et al (124) as being higher in patients with cancer compared with patients in the control group, a finding that contrasted with previous studies (139). The aforementioned study also noted a dramatic decrease of ghrelin levels following surgical removal of the tumors, advancing the possibility of a new early-warning marker of CRC and other GI tract malignancies (124).

A large case-control study published in 2018 demonstrated a positive correlation between decreased levels of ghrelin and the risk of developing CRC, spanning over a 10 -year period (143). Furthermore, a validation study comparing plasma ghrelin levels in 60 patients with CRC in a perioperative context and a 5-year interval preceding the diagnosis of CRC prior to surgery, demonstrated that ghrelin was not 
associated with an increased risk of malignancy, with ghrelin levels remaining stable over time (144).

Current data indicates that there are no significant changes in GHRL methylation levels (145). Furthermore, GHRL methylation is unlikely to become a biomarker of CRC, as no significant differences in hypermethylation of GHSR were observed in CRC compared with normal mucosa (145). This process is present in adenomas, irrespective of the degree of dysplasia, and results have not demonstrated any increase in hypermethylation correlated with tumor progression (145).

As in the case of esophageal cancer, it has been suggested that ghrelin plasma levels should not be interpreted in the absence of nutritional status and BMI (146). It is well documented that ghrelin levels increase in the case of cancer cachexia and decrease with obesity (147).

Neuroendocrine tumors (NETS) of the GI tract. Expression of ghrelin has been detected in NETs of gastropancreatic origin. Rindi et al (148) detected varying levels of ghrelin expression in digestive NETs, particularly in gastric tumors; these findings were supported by prior detection of ghrelin mRNA and were reported in other studies $(11,149)$. A study investigating NETs of the GI tract in patients with multiple endocrine neoplasia type 1 , determined that only $25 \%$ of cases were reported as ghrelin-positive and no clinicopathological correlation was established (150). The proportion of ghrelin-positive cells varied between 1 and 20\% $(148,150)$.

Pancreatic NETs express ghrelin in up to $95 \%$ of cases, validated by quantitative PCR (qPCR), whereas up to $67 \%$ of cases can be detected by IHC, with some tumors having only a small proportion of cells staining positively and others with $>80 \%$ positive cells $(148,151,152)$. Ghrelin expression has been documented in both functioning and non-functioning tumors of the pancreas (62 vs. 69\% of cases, respectively) (153). Papotti et al (149) demonstrated ghrelin expression in intestinal NETs; however, others did not find any ghrelin-positive intestinal NET cells $(148,153)$. Furthermore, the expression of ghrelin in neuroendocrine carcinoma was initially reported to be absent (148), whereas subsequent studies found ghrelin expression in scattered cells or focally in up to $10 \%$ of the tumor cells, which was associated with hyperghrelinemia $(154,155)$.

Plasma ghrelin levels in patients with gastroenteropancreatic NETs were initially demonstrated to not be significantly different between patients with tumors and healthy controls, neither initially, nor during progression of the disease $(153,156)$. A small subset of patients had high plasma ghrelin levels (>1280 ng/dl); however, two out of five such patients had tumors that had complete lack of ghrelin protein expression (153). In patients with metastatic disease, the levels of ghrelin were elevated, compared with the control group, in up to $85 \%$ of cases (157). A later study focusing on the active peripheral forms of ghrelin (acylated ghrelin; desacyl ghrelin; acylated ghrelin/desacyl ghrelin ratio) found no statistical difference between patients with NETs and the control group (158).

Luque et al (159) investigated the In1-ghrelin splice variant of the ghrelin gene in NETs and reported increased expression of In1-ghrelin in NETs compared with native ghrelin expression; these findings were confirmed in later years by another study (160). However, the differences in In1-ghrelin expression between the two studies demonstrated further the increased heterogeneity in NETs $(159,160)$. High levels of In1-ghrelin were detected in patients with metastasis (159).

Mesenchymal tumors. Although they are more rare than epithelial tumors, mesenchymal tumors of the GI tract contribute to the overall cancer burden of the region and may exhibit variable clinical behavior $(161,162)$. Among the most frequent are GI stromal tumors (GISTs) (161). Ghrelin expression in GISTs has only been reported by a single study, which found both IHC and qPCR-detectable expression, with $77 \%$ of analyzed tumors showing immunoreactivity for ghrelin and all tumors displaying detectable levels of ghrelin mRNA, albeit this analysis was performed on only about a third of the 22 cases (151). However, the study did not find any statistical correlation between ghrelin levels and tumor location, size, morphological parameters or clinical behavior (151), the value of these results being reiterated by another recent paper recognizing the potential role of the ghrelin axis in GISTs and supporting further research on this topic (163). Studies of large patient cohorts need to be implemented to better understand the role of the ghrelin axis in the pathogenesis of such tumors. However, limitations arise as a result of their low incidence and variability.

\section{Ghrelin interactions and expression in neoplasia outside the GI tract}

As previously mentioned, ghrelin and its receptors are expressed in numerous endocrine and non-endocrine tumor cell types, such as pituitary, prostate, breast and lung $(10,96,99,164)$. Since ghrelin acts not only as a local, but also as a systemic hormone, its potential role in cancer development in other organs has been investigated.

Oral SCC demonstrates the expression of the ghrelin axis, with ghrelin levels being negatively correlated with tumor invasiveness (165). Furthermore, decreasing ghrelin levels appear to be correlated with lower degrees of differentiation, indicating the potential value of tissue ghrelin expression as a prognostic marker (165). Another study demonstrated that expression of ghrelin and GHSR were gradually increased in oral tumors as benign cells developed cytological and architectural features of dysplasia and further progressed to becoming malignant (166).

An initial study on kidney tumors reported low to absent expression of ghrelin in RCC, with all 21 cases of conventional-subtype analyzed having no IHC ghrelin expression and partial-to-total loss of ghrelin expression when assessed through radioimmunoassays (167). However, certain kidney tumors, such as oncocytomas, did express ghrelin, albeit less than normal kidney tissue (167). Furthermore, Lin et al (94) assessed ghrelin expression levels in a cohort of 562 clear-cell type RCC cases and demonstrated that ghrelin levels were high and indicated a poor prognosis, with high ghrelin expression being associated with lymph node and distant metastases.

Ghrelin is expressed in both normal and tumoral breast tissue $(96,168)$. While ghrelin expression was investigated in normal mammary epithelium (168), Grönberg et al (169) also investigated ghrelin expression and the potential role of this hormone in male breast carcinogenesis, revealing that 
ghrelin expression was associated with a lower risk of breast cancer death. A study on 144 female breast cancer specimens determined ghrelin to be moderately to strongly expressed, which was positively correlated with survival and disease-free interval (92).

Cassoni et al (91) demonstrated prostatic adenocarcinomas were positive for ghrelin expression when assessed by reverse transcription-PCR but showed no immunoreactivity when assessed by IHC (91). Serum levels of ghrelin are higher in patients with prostate cancer compared with patients with benign prostate hyperplasia (170). Increased levels of In1-ghrelin and GOAT were also observed in patients with prostate cancer compared with a healthy control group (109).

Ghrelin may also serve a role in endometrial carcinogenesis through coupling with its GHSR1a receptor, with hormone and receptor expression detectable in benign and malignant tissue specimens (171). Expression has also been identified in various histological subtypes of lung cancer, accompanied by the expression of GHSR1a $(172,173)$.

\section{Conclusions}

The role of ghrelin in GI tract malignancies is still incompletely characterized. The complexity of the ghrelin axis and the interaction between this hormone and cancer cells is still unclear. Studies on cancer cell lines show a spectrum of ghrelin and ghrelin receptor expression, and new splice variants of ghrelin involved in carcinogenesis are emerging. The role of IHC to detect expression is unclear, as most papers do not focus on tumor histological subtype or other factors such as tumor heterogeneity. The use of ghrelin alone as a potential serological biomarker is debatable, as it is regulated by various metabolic factors and is linked with cancer-associated inflammation. Although certain of the effects of ghrelin can be quantified, there are still large discrepancies in this field owing to the variety of peripheral, circulating forms of ghrelin incompletely matched with a corresponding receptor. Further investigation is required to identify a potential desacyl ghrelin receptor that will facilitate the accurate identification of sites of action for this peptide and to elucidate its underlying mechanisms of action. The present review has demonstrated that our current understanding of the ghrelin system does not provide sufficient evidence to justify its role as a useful biomarker in GI malignancies. Therefore, large cohort studies with well-defined exclusion criteria and a complex framework, factoring in plasma levels, tissue expression and genetic alterations, are needed to establish direct correlations between ghrelin levels and GI malignancies.

\section{Acknowledgements}

Not applicable.

\section{Funding}

No funding was received.

\section{Availability of data and materials}

Not applicable.

\section{Authors' contributions}

IAS conceived the paper, designed the overall concept and created the figures. IDC supervised the project. IAS, IDC, DGAC and SEG contributed equally to collecting the data and in editing and shaping the manuscript. Data authentication is not applicable. All authors read and approved the final version of the manuscript.

\section{Ethics approval and consent to participate}

Not applicable.

\section{Patient consent for publication}

Not applicable.

\section{Competing interests}

The authors declare that they have no competing interests.

\section{References}

1. Kojima M, Hosoda H, Date Y, Nakazato M, Matsuo H and Kangawa K: Ghrelin is a growth-hormone-releasing acylated peptide from stomach. Nature 402: 656-660, 1999.

2. Stengel A, Goebel M, Wang L and Taché Y: Ghrelin, des-acyl ghrelin and nesfatin-1 in gastric X/A-like cells: Role as regulators of food intake and body weight. Peptides 31: 357-369, 2010.

3. Davis EA, Wald HS, Suarez AN, Zubcevic J, Liu CM, Cortella AM, Kamitakahara AK, Polson JW, Arnold M, Grill HJ, et al: Ghrelin signaling affects feeding behavior, metabolism, and memory through the vagus nerve. Curr Biol 30: 4510-4518.e6, 2020.

4. Cowley MA, Smith RG, Diano S, Tschöp M, Pronchuk N, Grove KL, Strasburger CJ, Bidlingmaier M, Esterman M, Heiman ML, et al: The distribution and mechanism of action of ghrelin in the CNS demonstrates a novel hypothalamic circuit regulating energy homeostasis. Neuron 37: 649-661, 2003.

5. Wren AM, Seal LJ, Cohen MA, Brynes AE, Frost GS, Murphy KG, Dhillo WS, Ghatei MA and Bloom SR: Ghrelin enhances appetite and increases food intake in humans. J Clin Endocrinol Metab 86: 5992, 2001.

6. Masuda Y, Tanaka T, Inomata N, Ohnuma N, Tanaka S, Itoh Z, Hosoda H, Kojima M and Kangawa K: Ghrelin stimulates gastric acid secretion and motility in rats. Biochem Biophys Res Commun 276: 905-908, 2000.

7. Carlini VP, Monzón ME, Varas MM, Cragnolini AB, Schiöth HB, Scimonelli TN and de Barioglio SR: Ghrelin increases anxiety-like behavior and memory retention in rats. Biochem Biophys Res Commun 299: 739-743, 2002.

8. Steiger A: Ghrelin and sleep-wake regulation. Am J Physiol Regul Integr Comp Physiol 292: R573-R574, 2007.

9. Engevik AC, Kaji I and Goldenring JR: The physiology of the gastric parietal cell. Physiol Rev 100: 573-602, 2020.

10. Korbonits M, Kojima M, Kangawa K and Grossman AB: Presence of ghrelin in normal and adenomatous human pituitary. Endocrine 14: 101-104, 2001.

11. Papotti M, Duregon E and Volante M: Ghrelin and tumors. Endocr Dev 25: 122-134, 2013.

12. Kojima $M$ and Kangawa K: Ghrelin: Structure and function. Physiol Rev 85: 495-522, 2005.

13. Fakhry J, Stebbing MJ, Hunne B, Bayguinov Y, Ward SM, Sasse KC, Callaghan B, McQuade RM and Furness JB: Relationships of endocrine cells to each other and to other cell types in the human gastric fundus and corpus. Cell Tissue Res 376: 37-49, 2019.

14. Gribble FM and Reimann F: Enteroendocrine cells: Chemosensors in the intestinal epithelium. Annu Rev Physiol 78: 277-299, 2016. 
15. Choi E, Roland JT, Barlow BJ, O'Neal R, Rich AE, Nam KT, Shi $\mathrm{C}$ and Goldenring JR: Cell lineage distribution atlas of the human stomach reveals heterogeneous gland populations in the gastric antrum. Gut 63: 1711-1720, 2014.

16. Sykaras AG, Demenis C, Cheng L, Pisitkun T, Mclaughlin JT, Fenton RA and Smith CP: Duodenal CCK cells from male mice express multiple hormones including ghrelin. Endocrinology 155 $3339-3351,2014$

17. Reynaud Y, Fakhry J, Fothergill L, Callaghan B, Ringuet M, Hunne B, Bravo DM and Furness JB: The chemical coding of 5-hydroxytryptamine containing enteroendocrine cells in the mouse gastrointestinal tract. Cell Tissue Res 364: 489-449, 2016

18. Fothergill LJ, Callaghan B, Hunne B, Bravo DM and Furness JB: Costorage of enteroendocrine hormones evaluated at the cell and subcellular levels in male mice. Endocrinology 158: 2113-2123, 2017

19. Glass LL, Calero-Nieto FJ, Jawaid W, Larraufie P, Kay RG Göttgens B, Reimann F and Gribble FM: Single-cell RNA-sequencing reveals a distinct population of proglucagon-expressing cells specific to the mouse upper small intestine. Mol Metab 6: 1296-1303, 2017.

20. Fothergill LJ and Furness JB: Diversity of enteroendocrine cells investigated at cellular and subcellular levels: The need for a new classification scheme. Histochem Cell Biol 150: 693-702, 2018.

21. Grönberg M, Tsolakis AV, Magnusson L, Janson ET and Saras J: Distribution of obestatin and ghrelin in human tissues: Immunoreactive cells in the gastrointestinal tract, pancreas, and mammary glands. J Histochem Cytochem 56: 793-801, 2008

22. Zhao Z and Sakai T: Characteristic features of ghrelin cells in the gastrointestinal tract and the regulation of stomach ghrelin expression and production. World J Gastroenterol 14: 6306-6311, 2008.

23. Teive MB, Russi RF, Vieira DS, Teive AM, Costa A and d'Acampora AJ: Quantitative immunohistochemical analysis of duodenal ghrelin cells after sleeve gastrectomy in Wistar rats. Acta Cir Bras 27: 595-599, 2012

24. Mehdar KM: The distribution of ghrelin cells in the human and animal gastrointestinal tract: A review of the evidence. Folia Morphol (Warsz) 80: 225-236, 2021.

25. Gnanapavan S, Kola B, Bustin SA, Morris DG, McGee P, Fairclough P, Bhattacharya S, Carpenter R, Grossman AB and Korbonits M: The tissue distribution of the mRNA of ghrelin and subtypes of its receptor, GHS-R, in humans. J Clin Endocrinol Metab 87: 2988, 2002

26. Santos M, Bastos P, Gonzaga S, Roriz JM, Baptista MJ, Nogueira-Silva C, Melo-Rocha G, Henriques-Coelho T, Roncon-Albuquerque R Jr, Leite-Moreira AF, et al: Ghrelin expression in human and rat fetal lungs and the effect of ghrelin administration in nitrofen-induced congenital diaphragmatic hernia. Pediatr Res 59: 531-537, 2006.

27. Jeffery PL, Murray RE, Yeh AH, McNamara JF, Duncan RP Francis GD, Herington AC and Chopin LK: Expression and function of the ghrelin axis, including a novel preproghrelin isoform, in human breast cancer tissues and cell lines. Endocr Relat Cancer 12: 839-850, 2005

28. Yeh AH, Jeffery PL, Duncan RP, Herington AC and Chopin LK Ghrelin and a novel preproghrelin isoform are highly expressed in prostate cancer and ghrelin activates mitogen-activated protein kinase in prostate cancer. Clin Cancer Res 11: 8295-8303, 2005.

29. Sato T, Nakamura Y, Shiimura Y, Ohgusu H, Kangawa K and Kojima M: Structure, regulation and function of ghrelin. J Biochem 151: 119-128, 2012.

30. Zhang JV, Ren PG, Avsian-Kretchmer O, Luo CW, Rauch R, Klein $\mathrm{C}$ and Hsueh AJ: Obestatin, a peptide encoded by the ghrelin gene, opposes ghrelin's effects on food intake. Science 310: 996-999, 2005.

31. Nishi Y, Yoh J, Hiejima H and Kojima M: Structures and molecular forms of the ghrelin-family peptides. Peptides 32 $2175-2182,2011$.

32. Hosoda H, Kojima M, Mizushima T, Shimizu S and Kangawa K: Structural divergence of human ghrelin. Identification of multiple ghrelin-derived molecules produced by post-translational processing. J Biol Chem 278: 64-70, 2003.

33. Pemberton C, Wimalasena P, Yandle T, Soule S and Richards $M$ C-terminal pro-ghrelin peptides are present in the human circulation. Biochem Biophys Res Commun 310: 567-573, 2003.

34. Hosoda H, Doi K, Nagaya N, Okumura H, Nakagawa E, Enomoto M, Ono F and Kangawa K: Optimum collection and storage conditions for ghrelin measurements: Octanoyl modification of ghrelin is rapidly hydrolyzed to desacyl ghrelin in blood samples. Clin Chem 50: 1077-1080, 2004.
35. Patterson M, Murphy KG, le Roux CW, Ghatei MA and Bloom SR: Characterization of ghrelin-like immunoreactivity in human plasma. J Clin Endocrinol Metab 90: 2205-2211, 2005.

36. Ibrahim Abdalla MM: Ghrelin-physiological functions and regulation. Eur Endocrinol 11: 90-95, 2015.

37. Delhanty PJ, Neggers SJ and van der Lely AJ: Mechanisms in endocrinology: Ghrelin: The differences between acyl- and des-acyl ghrelin. Eur J Endocrino 167: 601-608, 2012.

38. Lanfranco F, Baldi M,Cassoni P, Bosco M, Ghé C and Muccioli G: Ghrelin and prostate cancer. Vitam Horm 77: 301-324, 2008.

39. Gahete MD, Córdoba-Chacón J, Hergueta-Redondo M, Martínez-Fuentes AJ, Kineman RD, Moreno-Bueno G, Luque RM and Castaño JP: A novel human ghrelin variant (In1-ghrelin) and ghrelin-O-acyltransferase are overexpressed in breast cancer: Potential pathophysiological relevance. PLoS One 6: e23302, 2011

40. Gahete MD, Rincón-Fernández D, Villa-Osaba A, Hormaechea-Agulla D, Ibáñez-Costa A, Martínez-Fuentes AJ, Gracia-Navarro F, Castaño JP and Luque RM: Ghrelin gene products, receptors, and GOAT enzyme: Biological and pathophysiological insight. J Endocrinol 220: R1-R24, 2013.

41. Yang J, Brown MS, Liang G, Grishin NV and Goldstein JL: Identification of the acyltransferase that octanoylates ghrelin, an appetite-stimulating peptide hormone. Cell 132: 387-396, 2008.

42. Delporte C: Structure and physiological actions of ghrelin. Scientifica (Cairo) 2013: 518909, 2013.

43. Ferré G, Louet M, Saurel O, Delort B, Czaplicki G, M'Kadmi C, Damian M, Renault P, Cantel S, Gavara L, et al: Structure and dynamics of $\mathrm{G}$ protein-coupled receptor-bound ghrelin reveal the critical role of the octanoyl chain. Proc Natl Acad Sci USA 116: 17525-17530, 2019.

44. Rodríguez A, Gómez-Ambrosi J, Catalán V, Gil MJ, Becerril S, Sáinz N, Silva C, Salvador J, Colina I and Frühbeck G: Acylated and desacyl ghrelin stimulate lipid accumulation in human visceral adipocytes. Int J Obes (Lond) 33: 541-552, 2009.

45. Heppner KM, Piechowski CL, Müller A, Ottaway N, Sisley S, Smiley DL, Habegger KM, Pfluger PT, Dimarchi R, Biebermann $\mathrm{H}$, et al: Both acyl and des-acyl ghrelin regulate adiposity and glucose metabolism via central nervous system ghrelin receptors. Diabetes 63: 122-131, 2014

46. Howard AD, Feighner SD, Cully DF, Arena JP, Liberator PA, Rosenblum CI, Hamelin M, Hreniuk DL, Palyha OC, Anderson J, et al: A receptor in pituitary and hypothalamus that functions in growth hormone release. Science 273: 974-977, 1996.

47. Volante M, Fulcheri E, Allìa E, Cerrato M, Pucci A and Papotti M: Ghrelin expression in fetal, infant, and adult human lung. J Histochem Cytochem 50: 1013-1021, 2002.

48. Muccioli G, Baragli A, Granata R, Papotti M and Ghigo E: Heterogeneity of ghrelin/growth hormone secretagogue receptors. Toward the understanding of the molecular identity of novel ghrelin/GHS receptors. Neuroendocrinology 86: 147-164, 2007.

49. Ueberberg B, Unger N, Saeger W, Mann K and Petersenn S: Expression of ghrelin and its receptor in human tissues. Horm Metab Res 41: 814-821, 2009.

50. Xiao X, Bi M, Jiao Q, Chen X, Du X and Jiang H: A new understanding of GHSR la-independent of ghrelin activation. Ageing Res Rev 64: 101187, 2020.

51. Albarrán-Zeckler RG and Smith RG: The ghrelin receptors (GHS-R1a and GHS-R1b). Endocr Dev 25: 5-15, 2013.

52. Callaghan B and Furness JB: Novel and conventional receptors for ghrelin, desacyl-ghrelin, and pharmacologically related compounds. Pharmacol Rev 66: 984-1001, 2014.

53. Drucker DJ: Evolving concepts and translational relevance of enteroendocrine cell biology. J Clin Endocrinol Metab 101: 778-786, 2016.

54. Thompson NM, Gill DA, Davies R, Loveridge N, Houston PA, Robinson IC and Wells T: Ghrelin and des-octanoyl ghrelin promote adipogenesis directly in vivo by a mechanism independent of the type 1a growth hormone secretagogue receptor. Endocrinology 145: 234-242, 2004.

55. Churm R, Davies JS, Stephens JW and Prior SL: Ghrelin function in human obesity and type 2 diabetes: A concise review. Obes Rev 18: 140-148, 2017.

56. Toshinai K, Yamaguchi H, Sun Y, Smith RG, Yamanaka A, Sakurai T, Date Y, Mondal MS, Shimbara T, Kawagoe T, et al: Des-acyl ghrelin induces food intake by a mechanism independent of the growth hormone secretagogue receptor. Endocrinology 147: 2306-2314, 2006.

57. Au CC, Furness JB and Brown KA: Ghrelin and breast cancer: Emerging roles in obesity, estrogen regulation, and cancer. Front Oncol 6: 265, 2017. 
58. Rodríguez A, Gómez-Ambrosi J, Catalán V, Rotellar F, Valentí V, Silva C, Mugueta C, Pulido MR, Vázquez R, Salvador J, et al: The ghrelin $\mathrm{O}$-acyltransferase-ghrelin system reduces TNF- $\alpha$-induced apoptosis and autophagy in human visceral adipocytes. Diabetologia 55: 3038-3050, 2012.

59. Sheriff S, Kadeer N, Joshi R, Friend LA, James JH and Balasubramaniam A: Des-acyl ghrelin exhibits pro-anabolic and anti-catabolic effects on $\mathrm{C} 2 \mathrm{C} 12$ myotubes exposed to cytokines and reduces burn-induced muscle proteolysis in rats. Mol Cell Endocrinol 351: 286-295, 2012.

60. Wu R, Chaung WW, Dong W, Ji Y, Barrera R, Nicastro J, Molmenti EP, Coppa GF and Wang P: Ghrelin maintains the cardiovascular stability in severe sepsis. J Surg Res 178: 370-377, 2012.

61. Porporato PE, Filigheddu N, Reano S, Ferrara M, Angelino E, Gnocchi VF, Prodam F, Ronchi G, Fagoonee S, Fornaro M, et al: Acylated and unacylated ghrelin impair skeletal muscle atrophy in mice. J Clin Invest 123: 611-622, 2013.

62. Bouillon-Minois JB, Trousselard M, Thivel D, Gordon BA, Schmidt J, Moustafa F, Oris C and Dutheil F: Ghrelin as a biomarker of stress: A systematic review and meta-analysis. Nutrients 13: 784, 2021.

63. Gray SM, Page LC and Tong J: Ghrelin regulation of glucose metabolism. J Neuroendocrinol 31: e12705, 2019.

64. Nass RM, Gaylinn BD, Rogol AD and Thorner MO: Ghrelin and growth hormone: Story in reverse. Proc Natl Acad Sci USA 107: 8501-8502, 2010.

65. Quiñones M, Fern $\varnothing \mathrm{J}$ and Al-Massadi O: Ghrelin and liver disease. Rev Endocr Metab Disord 21: 45-56, 2020.

66. Akalu Y, Molla MD, Dessie G and Ayelign B: Physiological effect of ghrelin on body systems. Int J Endocrinol 2020: 1385138,2020

67. Tschöp M, Smiley DL and Heiman ML: Ghrelin induces adiposity in rodents. Nature 407: 908-913, 2000.

68. Mihalache L, Arhire LI, Giuşcă SE, Gherasim A, Niţă O, Constantinescu D, Constantinescu RN, Pădureanu SS and Danciu M: Ghrelin-producing cells distribution in the stomach and the relation with Helicobacter pylori in obese patients. Rom J Morphol Embryol 60: 219-225, 2019.

69. Chowen JA and Argente J: Ghrelin: A link between energy homeostasis and the immune system. Endocrinology 158: 2077-2081, 2017.

70. Dixit VD, Schaffer EM, Pyle RS, Collins GD, Sakthivel SK, Palaniappan R, Lillard JW Jr and Taub DD: Ghrelin inhibits leptinand activation-induced proinflammatory cytokine expression by human monocytes and T cells. J Clin Invest 114: 57-66, 2004

71. Kasımay O, Ișeri SO, Barlas A, Bangir D, Yeğen C, Arbak S and Yeğen BC: Ghrelin ameliorates pancreaticobiliary inflammation and associated remote organ injury in rats. Hepatol Res 36: 11-19, 2006.

72. Huang CX, Yuan MJ, Huang H, Wu G, Liu Y, Yu SB, Li HT and Wang T: Ghrelin inhibits post-infarct myocardial remodeling and improves cardiac function through anti-inflammation effect. Peptides 30: 2286-2291, 2009.

73. Chang RJ, Wang HL, Qin MB, Liang ZH, He JP, Wei YL, Fu HZ and Tang GD: Ghrelin inhibits IKK $\beta / \mathrm{NF}-\kappa \mathrm{B}$ activation and reduces pro-inflammatory cytokine production in pancreatic acinar AR42J cells treated with cerulein. Hepatobiliary Pancreat Dis Int: Jun 2, 2020 (Online ahead of print).

74. Mao Y, Wang J, Yu F, Cheng J, Li H, Guo C and Fan X: Ghrelin reduces liver impairment in a model of concanavalin A-induced acute hepatitis in mice. Drug Des Devel Ther 9: 5385-5396, 2015.

75. Karmiris K, Koutroubakis IE, Xidakis C, Polychronaki M, Voudouri T and Kouroumalis EA: Circulating levels of leptin, adiponectin, resistin, and ghrelin in inflammatory bowel disease. Inflamm Bowel Dis 12: 100-105, 2006.

76. Theil MM, Miyake S, Mizuno M, Tomi C, Croxford JL, Hosoda H, Theil J, von Hörsten S, Yokote H, Chiba A, et al: Suppression of experimental autoimmune encephalomyelitis by ghrelin. J Immunol 183: 2859-2866, 2009.

77. Granado M, Priego T, Martín AI, Villanúa MA and LópezCalderón A: Anti-inflammatory effect of the ghrelin agonist growth hormone-releasing peptide-2 (GHRP-2) in arthritic rats. Am J Physiol Endocrinol Metab 288: E486-E492, 2005.

78. Gonzalez-Rey E, Chorny A and Delgado M: Therapeutic action of ghrelin in a mouse model of colitis. Gastroenterology 130 : $1707-1720,2006$

79. Liu H, Luo J, Guillory B, Chen JA, Zang P, Yoeli JK, Hernandez Y, Lee II, Anderson B, Storie M, et al: Ghrelin ameliorates tumor-induced adipose tissue atrophy and inflammation via Ghrelin receptor-dependent and -independent pathways. Oncotarget 11: 3286-3302, 2020.
80. Lacerda-Miranda G, Soares VM, Vieira AK, Lessa JG, Rodrigues-Cunha AC, Cortez E, Garcia-Souza EP and Moura AS: Ghrelin signaling in heart remodeling of adult obese mice. Peptides 35: 65-73, 2012

81. Sullivan R, McGirr R, Hu S, Tan A, Wu D, Charron C, Lalonde T, Arany E, Chakrabarti S, Luyt L and Dhanvantari S: Changes in the cardiac GHSR1a-ghrelin system correlate with myocardial dysfunction in diabetic cardiomyopathy in mice. J Endocr Soc 2: 178-189, 2017.

82. Grossini E, Raina G, Farruggio S, Camillo L, Molinari C, Mary D, Walker GE, Bona G, Vacca G, Moia S, et al: Intracoronary des-acyl ghrelin acutely increases cardiac perfusion through a nitric oxide-related mechanism in female anesthetized pigs. Endocrinology 157: 2403-2415, 2016.

83. Soeki T, Kishimoto I, Schwenke DO, Tokudome T, Horio T, Yoshida M, Hosoda $\mathrm{H}$ and Kangawa K: Ghrelin suppresses cardiac sympathetic activity and prevents early left ventricular remodeling in rats with myocardial infarction. Am J Physiol Heart Circ Physiol 294: H426-H432, 2008.

84. Henriques-Coelho T, Correia-Pinto J, Roncon-Albuquerque R Jr, Baptista MJ, Lourenço AP, Oliveira SM, Brandão-Nogueira A, Teles A, Fortunato JM and Leite-Moreira AF: Endogenous production of ghrelin and beneficial effects of its exogenous administration in monocrotaline-induced pulmonary hypertension. Am J Physiol Heart Circ Physiol 287: H2885-H2890, 2004.

85. Wu R, Dong W, Zhou M, Zhang F, Marini CP, Ravikumar TS and Wang P: Ghrelin attenuates sepsis-induced acute lung injury and mortality in rats. Am J Respir Crit Care Med 176: 805-813, 2007.

86. DeBoer MD, Zhu XX, Levasseur P, Meguid MM, Suzuki S, Inui A, Taylor JE, Halem HA, Dong JZ, Datta R, et al: Ghrelin treatment causes increased food intake and retention of lean body mass in a rat model of cancer cachexia. Endocrinology 148: 3004-3012, 2007.

87. Wang W, Andersson M, Iresjö BM, Lönnroth C and Lundholm K Effects of ghrelin on anorexia in tumor-bearing mice with eicosanoid-related cachexia. Int J Oncol 28: 1393-1400, 2006

88. Bayliss JA, Lemus MB, Stark R, Santos VV, Thompson A, Rees DJ, Galic S, Elsworth JD, Kemp BE, Davies JS and Andrews ZB: Ghrelin-AMPK signaling mediates the neuroprotective effects of calorie restriction in Parkinson's disease. J Neurosci 36: 3049-3063, 2016.

89. Unger MM, Oertel WH and Tackenberg B: Cerebrospinal fluid concentrations of ghrelin in patients with multiple sclerosis. Neuro Endocrinol Lett 34: 14-17, 2013.

90. Ngo ST, Steyn FJ, Huang L, Mantovani S, Pfluger CM, Woodruff TM, O'Sullivan JD, Henderson RD and McCombe PA: Altered expression of metabolic proteins and adipokines in patients with amyotrophic lateral sclerosis. J Neurol Sci 357: 22-27, 2015.

91. Cassoni P, Ghé C, Marrocco T, Tarabra E, Allia E, Catapano F, Deghenghi R, Ghigo E, Papotti M and Muccioli G: Expression of ghrelin and biological activity of specific receptors for ghrelin and des-acyl ghrelin in human prostate neoplasms and related cell lines. Eur J Endocrinol 150: 173-184, 2004

92. Grönberg M, Fjällskog ML, Jirström K and Janson ET: Expression of ghrelin is correlated to a favorable outcome in invasive breast cancer. Acta Oncol 51: 386-393, 2012.

93. Sadjadi A, Yazdanbod A, Lee YY, Boreiri M, Samadi F, Alizadeh BZ, Islami F, Fyfe V, Babaei M, Namazi MJ, et al: Serum ghrelin; a new surrogate marker of gastric mucosal alterations in upper gastrointestinal carcinogenesis. PLoS One 8: e74440, 2013

94. Lin TC, Liu YP, Chan YC, Su CY, Lin YF, Hsu SL, Yang CS and Hsiao M: Ghrelin promotes renal cell carcinoma metastasis via Snail activation and is associated with poor prognosis. J Pathol 237: 50-61, 2015.

95. De Vriese C and Delporte C: Autocrine proliferative effect of ghrelin on leukemic HL-60 and THP-1 cells. J Endocrinol 192: 199-205, 2007

96. Cassoni P, Papotti M, Ghè C, Catapano F, Sapino A, Graziani A, Deghenghi R, Reissmann T, Ghigo E and Muccioli G: Identification, characterization, and biological activity of specific receptors for natural (ghrelin) and synthetic growth hormone secretagogues and analogs in human breast carcinomas and cell lines. J Clin Endocrinol Metab 86: 1738-1745, 2001.

97. Tsubouchi H, Onomura H, Saito Y, Yanagi S, Miura A, Matsuo A, Matsumoto $\mathrm{N}$ and Nakazato M: Ghrelin does not influence cancer progression in a lung adenocarcinoma cell line. Endocr J 64 (Suppl 1): S41-S46, 2017 
98. Duxbury MS, Waseem T, Ito H, Robinson MK, Zinner MJ, Ashley SW and Whang EE: Ghrelin promotes pancreatic adenocarcinoma cellular proliferation and invasiveness. Biochem Biophys Res Commun 309: 464-468, 2003.

99. Jeffery PL, Herington AC and Chopin LK: Expression and action of the growth hormone releasing peptide ghrelin and its receptor in prostate cancer cell lines. J Endocrinol 172: R7-R11, 2002.

100. Tian C, Zhang L, Hu D and Ji J: Ghrelin induces gastric cancer cell proliferation, migration, and invasion through GHS-R/NF- $\mathrm{B}$ signaling pathway. Mol Cell Biochem 382: 163-172, 2013.

101. Waseem T, Javaid-Ur-Rehman, Ahmad F, Azam M and Qureshi MA: Role of ghrelin axis in colorectal cancer: A novel association. Peptides 29: 1369-1376, 2008

102. Lien GS, Lin CH, Yang YL, Wu MS and Chen BC: Ghrelin induces colon cancer cell proliferation through the GHS-R, Ras, PI3K, Akt, and mTOR signaling pathways. Eur J Pharmacol 776: 124-131, 2016

103. Kraus D, Reckenbeil J, Wenghoefer M, Stark H, Frentzen M, Allam JP, Novak N, Frede S, Götz W, Probstmeier R, et al: Ghrelin promotes oral tumor cell proliferation by modifying GLUT1 expression. Cell Mol Life Sci 73: 1287-1299, 2016.

104. Waseem T, Duxbury M, Ashley SW and Robinson MK Ghrelin promotes intestinal epithelial cell proliferation through PI3K/Akt pathway and EGFR trans-activation both converging to ERK 1/2 phosphorylatio. Peptides 52: 113-121, 2014.

105. Barzon L, Pacenti M, Masi G, Stefani AL, Fincati K and Palù G: Loss of growth hormone secretagogue receptor 1a and overexpression of type $1 \mathrm{~b}$ receptor transcripts in human adrenocortical tumors. Oncology 68: 414-421, 2005.

106. Fung JN, Seim I, Wang D, Obermair A, Chopin LK and Chen C: Expression and in vitro functions of the ghrelin axis in endometrial cancer. Horm Cancer 1: 245-255, 2010.

107. Lawnicka H, Mełeń-Mucha G, Motylewska E, Mucha S and Stepien H: Modulation of ghrelin axis influences the growth of colonic and prostatic cancer cells in vitro. Pharmacol Rep 64 951-959, 2012

108. El-Kott AF, Shati AA, Al-Kahtani MA and Alqahtani S: Acylated ghrelin renders chemosensitive ovarian cancer cells resistant to cisplatin chemotherapy via activation of the PI3K/Akt/mTOR survival pathway. Anal Cell Pathol (Amst) 2019: 9627810, 2019.

109. Rincón-Fernández D, Culler MD, Tsomaia N, Moreno-Bueno G, Luque RM, Gahete MD and Castaño JP: In1-ghrelin splicing variant is associated with reduced disease-free survival of breast cancer patients and increases malignancy of breast cancer cells lines. Carcinogenesis 39: 447-457, 2018.

110. Hormaechea-Agulla D, Gahete MD, Jiménez-Vacas JM, Gómez-Gómez E, Ibáñez-Costa A, L-López F, Rivero-Cortés E, Sarmento-Cabral A, Valero-Rosa J, Carrasco-Valiente J, et al The oncogenic role of the In1-ghrelin splicing variant in prostate cancer aggressiveness. Mol Cancer 16: 146, 2017.

111. Chen JH, Huang SM, Chen CC, Tsai CF, Yeh WL, Chou SJ, Hsieh WT and Lu DY: Ghrelin induces cell migration through GHS-R, CaMKII, AMPK, and NF- $\kappa \mathrm{B}$ signaling pathway in glioma cells. J Cell Biochem 112: 2931-2941, 2011.

112. Lin TC, Yeh YM, Fan WL, Chang YC, Lin WM, Yang TY and Hsiao M: Ghrelin upregulates oncogenic Aurora A to promote renal cell carcinoma invasion. Cancers (Basel) 11: 303, 2019.

113. Tiaka EK, Manolakis AC, Kapsoritakis AN and Potamianos SP: Unraveling the link between leptin, ghrelin and different types of colitis. Ann Gastroenterol 24: 20-28, 2011.

114. Ghomraoui FA, Alotaibi ST, Alharthi MA, Asiri SS, Almadi MA, Alharbi OR, Azzam NA, Aljebreen AM, Saeed M, Hajkhder B, et al: Plasma ghrelin and leptin in patients with inflammatory bowel disease and its association with nutritional status. Saudi J Gastroenterol 23: 199-205, 2017.

115. Omoto I, Matsumoto M, Uchikado Y, Kita Y, Sakurai T, Sasaki K, Setoyama T, Okumura H, Owaki T, Ishigami S and Natsugoe S: Immunohistochemical evidence of association between ghrelin expression and tumor growth in esophageal carcinoma. Anticancer Res 34: 2727-2733, 2014

116. Mottershead M, Karteris E, Barclay JY, Suortamo S, Newbold M, Randeva $\mathrm{H}$ and Nwokolo $\mathrm{CU}$ : Immunohistochemical and quantitative mRNA assessment of ghrelin expression in gastric and oesophageal adenocarcinoma. J Clin Pathol 60: 405-409, 2007.

117. Murphy G, Kamangar F, Albanes D, Stanczyk FZ, Weinstein SJ, Taylor PR, Virtamo J, Abnet CC, Dawsey SM and Freedman ND: Serum ghrelin is inversely associated with risk of subsequent oesophageal squamous cell carcinoma. Gut 61: 1533-1537, 2012.
118. Pritchett NR, Maziarz M, Shu XO, Kamangar F, Dawsey SM, Fan JH, Ji BT, Gao YT, Xiang YB, Qiao YL, et al: Serum ghrelin and esophageal and gastric cancer in two cohorts in China. Int J Cancer 146: 2728-2735, 2020

119. de Martel C, Haggerty TD, Corley DA, Vogelman JH, Orentreich N and Parsonnet J: Serum ghrelin levels and risk of subsequent adenocarcinoma of the esophagus. Am J Gastroenterol 102: 1166-1172, 2007.

120. Thomas SJ, Almers L, Schneider J, Graham JE, Havel PJ and Corley DA: Ghrelin and leptin have a complex relationship with risk of Barrett's esophagus. Dig Dis Sci 61: 70-79, 2016.

121. Rubenstein JH, Morgenstern H, McConell D, Scheiman JM, Schoenfeld P, Appelman H, McMahon LF Jr, Kao JY, Metko V, Zhang $\mathrm{M}$ and Inadomi JM: Associations of diabetes mellitus, insulin, leptin, and ghrelin with gastroesophageal reflux and Barrett's esophagus. Gastroenterolog 145: 1237-1244.el-e5, 2013.

122. Konturek PC, Burnat G, Rau T, Hahn EG and Konturek S: Effect of adiponectin and ghrelin on apoptosis of Barrett adenocarcinoma cell line. Dig Dis Sci 53: 597-605, 2008

123. Xie SH, Rabbani S, Ness-Jensen E and Lagergren J: Circulating levels of inflammatory and metabolic biomarkers and risk of esophageal adenocarcinoma and Barrett esophagus: Systematic review and meta-analysis. Cancer Epidemiol Biomarkers Prev 29: 2109-2118, 2020.

124. Zhu C, Liu Y, Kang W, Zhang Z, Zeng Z and Liu D: Exploration of the role of serum ghrelin in the diagnosis and treatment of digestive tract malignancies. J Int Med Res 48: 300060520920441 , 2020.

125. Shinsyu A, Bamba S, Kurihara M, Matsumoto H, Sonoda A, Inatomi O, Andoh A, Takebayashi K, Kojima M, Iida H, et al: Inflammatory cytokines, appetite-regulating hormones, and energy metabolism in patients with gastrointestinal cancer. Oncol Lett 20: 1469-1479, 2020.

126. Chen JH, Zhai ET, Yuan YJ, Wu KM, Xu JB, Peng JJ, Chen CQ, He YL and Cai SR: Systemic immune-inflammation index for predicting prognosis of colorectal cancer. World J Gastroenterol 23: 6261-6272, 2017.

127. Chang WJ, Du Y, Zhao X, Ma LY and Cao GW: Inflammation-related factors predicting prognosis of gastric cancer. World J Gastroenterol 20: 4586-4596, 2014.

128. Aydin S, Ozercan IH, Dagli F, Aydin S, Dogru O, Celebi S, Akin $O$ and Guzel SP: Ghrelin immunohistochemistry of gastric adenocarcinoma and mucoepidermoid carcinoma of salivary gland. Biotech Histochem 80: 163-168, 2005.

129. An JY, Choi MG, Noh JH, Sohn TS, Jin DK and Kim S: Clinical significance of ghrelin concentration of plasma and tumor tissue in patients with gastric cancer. J Surg Res 143: 344-349, 2007.

130. Murphy G, Kamangar F, Dawsey SM, Stanczyk FZ, Weinstein SJ, Taylor PR, Virtamo J, Abnet CC, Albanes D and Freedman ND: The relationship between serum ghrelin and the risk of gastric and esophagogastric junctional adenocarcinomas. J Natl Cancer Inst 103: 1123-1129, 2011.

131. Nwokolo CU, Freshwater DA, O'Hare P and Randeva HS Plasma ghrelin following cure of Helicobacter pylori. Gut 52: 637-640, 2003.

132. Osawa H, Nakazato M, Date Y, Kita H, Ohnishi H, Ueno H, Shiiya T, Satoh K, Ishino Y and Sugano K: Impaired production of gastric ghrelin in chronic gastritis associated with Helicobacter pylori. J Clin Endocrinol Metab 90: 10-16, 2005.

133. Zub-Pokrowiecka A, Rembiasz K, Konturek PC, Budzyński A, Konturek SJ, Winiarski M and Bielański W: Ghrelin and gastrin in advanced gastric cancer before and after gastrectomy. World J Gastroenterol 17: 449-458, 2011.

134. Jeon TY, Lee S, Kim HH, Kim YJ, Son HC, Kim DH and Sim MS: Changes in plasma ghrelin concentration immediately after gastrectomy in patients with early gastric cancer. J Clin Endocrinol Metab 89: 5392-5396, 2004.

135. Takachi K, Doki Y, Ishikawa O, Miyashiro I, Sasaki Y, Ohigashi H, Murata K, Nakajima H, Hosoda H, Kangawa K, et al: Postoperative ghrelin levels and delayed recovery from body weight loss after distal or total gastrectomy. J Surg Res 130: 1-7, 2006 .

136. Wu X, Wu Y, Ye B, Wu F and Wang P: High expression of ghrelin and obestatin prepropeptide in tumor tissues predicted adverse overall survival in gastric carcinoma patients. Medicine (Baltimore) 99: e20635, 2020

137. Wolf I, Sadetzki S, Kanety H, Kundel Y, Pariente C, Epstein N, Oberman B, Catane R, Kaufman B and Shimon I: Adiponectin, ghrelin, and leptin in cancer cachexia in breast and colon cancer patients. Cancer 106: 966-973, 2006. 
138. Liu A, Huang C, Xu J and Cai X: Lentivirus-mediated shRNA interference of ghrelin receptor blocks proliferation in the colorectal cancer cells. Cancer Med 5: 2417-2426, 2016.

139. Huang Q, Fan YZ, Ge BJ, Zhu Q and Tu ZY: Circulating ghrelin in patients with gastric or colorectal cancer. Dig Dis Sci 52: 803-809, 2007.

140. D'Onghia V, Leoncini R, Carli R, Santoro A, Giglioni S, Sorbellini F, Marzocca G, Bernini A, Campagna S, Marinello E and Vannoni D: Circulating gastrin and ghrelin levels in patients with colorectal cancer: Correlation with tumour stage, Helicobacter pylori infection and BMI. Biomed Pharmacother 61: 137-141, 2007.

141. Nikolopoulos D, Theocharis S, Moutsios-Rentzos A, Kouraklis G and Kostakis A: The role of serum total ghrelin level elevation in colon cancer patients. J BUON 19: 388-393, 2014.

142. Kemik O, Sumer A, Kemik AS, Hasirci I, Purisa S, Dulger AC, Demiriz B and Tuzun S: The relationship among acute-phase response proteins, cytokines and hormones in cachectic patients with colon cancer. World J Surg Oncol 8: 85, 2010.

143. Murphy G, Cross AJ, Dawsey SM, Stanczyk FZ, Kamangar F, Weinstein SJ, Taylor PR, Männistö S, Albanes D, Abnet CC and Freedman ND: Serum ghrelin is associated with risk of colorectal adenocarcinomas in the ATBC study. Gut 67: 1646-1651, 2018.

144. Sundkvist A, Myte R, Palmqvist R, Harlid S and Van Guelpen B: Plasma ghrelin is probably not a useful biomarker for risk prediction or early detection of colorectal cancer. Gut 68 373-374, 2019

145. Coppedè F, Stoccoro A, Lazzarotti A, Spisni R and Migliore L: Investigation of GHSR and GHRL methylation in colorectal cancer. Epigenomics 10: 1525-1539, 2018.

146. Chopin LK, Seim I, Walpole CM and Herington AC: The ghrelin axis-does it have an appetite for cancer progression? Endocr Rev 33: 849-891, 2012.

147. Molfino A, Formiconi A, Rossi Fanelli F and Muscaritoli M: Ghrelin: From discovery to cancer cachexia therapy. Curr Opin Clin Nutr Metab Care 17: 471-476, 2014.

148. Rindi G, Savio A, Torsello A, Zoli M, Locatelli V, Cocchi D, Paolotti D and Solcia E: Ghrelin expression in gut endocrine growths. Histochem Cell Biol 117: 521-525, 2002

149. Papotti M, Cassoni P, Volante M, Deghenghi R, Muccioli G and Ghigo E: Ghrelin-producing endocrine tumors of the stomach and intestine. J Clin Endocrinol Metab 86: 5052-5059, 2001.

150. Raffel A, Krausch M, Cupisti K, Gerharz CD, Eisenberger CF and Knoefel WT: Ghrelin expression in neuroendocrine tumours of the gastrointestinal tract with multiple endocrine neoplasia type 1. Horm Metab Res 37: 653-655, 2005.

151. Ekeblad S, Nilsson B, Lejonklou MH, Johansson T, Stålberg P, Nilsson O, Ahlman H and Skogseid B: Gastrointestinal stromal tumors express the orexigen ghrelin. Endocr Relat Cancer 13: 963-970, 2006

152. Volante M, Allìa E, Gugliotta P,Funaro A, Broglio F, Deghenghi R, Muccioli G, Ghigo E and Papotti M: Expression of ghrelin and of the GH secretagogue receptor by pancreatic islet cells and related endocrine tumors. J Clin Endocrinol Metab 87: 1300-1308, 2002.

153. Ekeblad S, Lejonklou MH, Grimfjärd P, Johansson T, Eriksson B Grimelius L, Stridsberg M, Stålberg P and Skogseid B: Co-expression of ghrelin and its receptor in pancreatic endocrine tumours. Clin Endocrinol (Oxf) 66: 115-122, 2007.

154. Tsolakis AV, Stridsberg M, Grimelius L, Portela-Gomes GM, Falkmer SE, Waldum HL and Janson ET: Ghrelin immunoreactive cells in gastric endocrine tumors and their relation to plasma ghrelin concentration. J Clin Gastroenterol 42: 381-388, 2008.

155. Walter T, Chardon L, Hervieu V, Cohen R, Chayvialle JA, Scoazec JY and Lombard-Bohas C: Major hyperghrelinemia in advanced well-differentiated neuroendocrine carcinomas: Report of three cases. Eur J Endocrino 161: 639-645, 2009.

156. Corbetta S, Peracchi M, Cappiello V, Lania A, Lauri E, Vago L, Beck-Peccoz P and Spada A: Circulating ghrelin levels in patients with pancreatic and gastrointestinal neuroendocrine tumors: Identification of one pancreatic ghrelinoma. J Clin Endocrinol Metab 88: 3117-3120, 2003
157. Wang HS, Oh DS, Ohning GV and Pisegna JR: Elevated serum ghrelin exerts an orexigenic effect that may maintain body mass index in patients with metastatic neuroendocrine tumors. J Mol Neurosci 33: 225-231, 2007

158. van Adrichem RC, van der Lely AJ, Huisman M, Kramer P Feelders RA, Delhanty PJ and de Herder WW: Plasma acylated and plasma unacylated ghrelin: Useful new biomarkers in patients with neuroendocrine tumors? Endocr Connect 5: 143-151, 2016.

159. Luque RM, Sampedro-Nuñez M, Gahete MD, Ramos-Levi A, Ibáñez-Costa A, Rivero-Cortés E, Serrano-Somavilla A, Adrados M, Culler MD, Castaño JP and Marazuela M: In1-ghrelin, a splice variant of ghrelin gene, is associated with the evolution and aggressiveness of human neuroendocrine tumors: Evidence from clinical, cellular and molecular parameters. Oncotarget 6: 19619-19633, 2015.

160. Herrera-Martínez AD, Gahete MD, Sánchez-Sánchez R, Alors-Perez E, Pedraza-Arevalo S, Serrano-Blanch R, Martínez-Fuentes AJ, Gálvez-Moreno MA, Castaño JP and Luque RM: Ghrelin-O-acyltransferase (GOAT) enzyme as a novel potential biomarker in gastroenteropancreatic neuroendocrine tumors. Clin Transl Gastroenterol 9: 196, 2018.

161. Hirota S: Differential diagnosis of gastrointestinal stromal tumor by histopathology and immunohistochemistry. Transl Gastroenterol Hepatol 3: 27, 2018

162. Doyle LA and Hornick JL: Gastrointestinal stromal tumours: From KIT to succinate dehydrogenase. Histopathology 64 : 53-67, 2014

163. Zhu CZ, Liu D, Kang WM, Yu JC, MaZQ, Ye X and Li K: Ghrelin and gastrointestinal stromal tumors. World J Gastroenterol 23: $1758-1763,2017$

164. Ghè C, Cassoni P, Catapano F, Marrocco T, Deghenghi R, Ghigo E, Muccioli G and Papotti M: The antiproliferative effect of synthetic peptidyl GH secretagogues in human CALU-1 lung carcinoma cells. Endocrinology 143: 484-491, 2002.

165. Alnema MM, Aydin S, Ozkan Y, Dagli AF, Ozercan HI, Yildirim N, Sahin I, Karaoglu A, Kilic N, Yilmaz M, et al: Ghrelin and obestatin expression in oral squamous cell carcinoma: An immunohistochemical and biochemical study. Mol Cell Biochem 339: 173-179, 2010.

166. Lou J, Liu L, Zhang W, Zhou Z and Fan Y: Differential expression of ghrelin and GHSR via the mTOR pathway during the dynamic carcinogenic process involving oral, potentially malignant disorders. Biosci Rep 39: BSR20192102, 2019.

167. Dagli AF, Aydin S, Karaoglu A, Akpolat N, Ozercan IH and Ozercan MR: Ghrelin expression in normal kidney tissue and renal carcinomas. Pathol Res Pract 205: 165-173, 2009.

168. Grönberg M, Amini RM, Stridsberg M, Janson ET and Saras J: Neuroendocrine markers are expressed in human mammary glands. Regul Pept 160: 68-74, 2010.

169. Grönberg M, Nilsson C, Markholm I, Hedenfalk I, Blomqvist C, Holmberg L, Tiensuu Janson E and Fjällskog ML: Ghrelin expression is associated with a favorable outcome in male breast cancer. Sci Rep 8: 13586, 2018.

170. Malendowicz W,Ziolkowska A, Szyszka M and Kwias Z: Elevated blood active ghrelin and unaltered total ghrelin and obestatin concentrations in prostate carcinoma. Urol Int 83: 471-475, 2009.

171. Fung JN, Jeffery PL, Lee JD, Seim I, Roche D, Obermair A, Chopin LK and Chen C: Silencing of ghrelin receptor expression inhibits endometrial cancer cell growth in vitro and in vivo. Am J Physiol Endocrinol Metab 305: E305-E313, 2013.

172. Kerenidi T, Lada M, Tsaroucha A, Georgoulias P, Mystridou P and Gourgoulianis KI: Clinical significance of serum adipokines levels in lung cancer. Med Oncol 30: 507, 2013.

173. Li X, Zhao X, Li C, Liu S, Yan F, Teng Y, Feng J and Miao D: Inhibitor of ghrelin receptor reverses gefitinib resistance in lung cancer. Hum Cell 32: 360-366, 2019.

This work is licensed under a Creative Commons Attribution-NonCommercial-NoDerivatives 4.0 International (CC BY-NC-ND 4.0) License. 